\title{
Antimycobacterial activity and low cytotoxicity of leaf extracts of some African
}

\section{Anacardiaceae tree species.}

\section{Short Title: Antimycobacterial and cytotoxicity of Anacardiaceae tree species}

Prudence N. Kabongo-Kayoka ${ }^{1,2}$, Jacobus N. Eloff ${ }^{2}$, Chikwelu L. Obi ${ }^{3}$, Lyndy J. McGaw ${ }^{2}$

${ }^{1}$ Department of Agriculture and Animal Health, College of Agriculture and Environmental

Sciences, University of South Africa, Private Bag X 6, Florida 1710, South Africa;

kabonpnk@unisa.ac.za

${ }^{2}$ Phytomedicine Programme, Department of Paraclinical Sciences, Faculty of Veterinary

Science, University of Pretoria, Private Bag X04, Onderstepoort 0110, South Africa

${ }^{3}$ Division of Academic Affairs, University of Fort Hare, Alice 5700, South Africa

*Corresponding author.

E-mail address: kabonpnk@unisa.ac.za (P.N. Kabongo-Kayoka)

Treatment of tuberculosis is a challenge due to multi and extremely drug resistant strains of Mycobacterium tuberculosis. Plant species contain antimicrobial compounds that may lead to new anti-TB drugs. Previous screening of some tree species from the Anacardiaceae family revealed the presence of antimicrobial activity, justifying further investigations. Leaf extracts of 15 Anacardiaceae tree species were screened for antimycobacterial activity using a twofold serial microdilution assay against the pathogenic Mycobacterium bovis and multidrug resistant $M$. tuberculosis and rapidly growing mycobacteria, Mycobacterium smegmatis, Mycobacterium fortuitum and Mycobacterium aurum. The vaccine strain, $M$. bovis and an avirulent strain, H37Ra M. tuberculosis, were also used. Cytotoxicity was assessed using a colorimetric assay against Vero kidney, human hepatoma and murine macrophage cells. Four out of 15 crude 
acetone extracts showed significant antimycobacterial activity with MIC varying from 50 to $100 \mu \mathrm{g} / \mathrm{mL}$. Searsia undulata had the highest activity against most mycobacteria, followed by Protorhus longifolia. M. fortuitum was the strongest predictor of activity against MDR-TB (correlation coefficient=0.65). Bioautography against $M$. aurum and $M$. fortuitum worked well as indicators of the $\mathrm{Rf}$ values of active compounds yielding strong zones of inhibition. The leaf extracts of $S$. undulata and $P$. longifolia had more than 10 different antimycobacterial compounds and had low cytotoxicity with $\mathrm{LC}_{50}$ values above $100 \mu \mathrm{g} / \mathrm{ml}$.

Keywords: Anacardiaceae; MDR-M. tuberculosis; antimycobacterial; cytotoxicity; selectivity 


\section{Background}

Tuberculosis occurs in humans, cattle, wild animals and many other domesticated species. The Mycobacterium tuberculosis complex (MTC) comprises M. tuberculosis, M. bovis, $M$. africanum, M. canetti, M. pinnipedii, M. caprae, M. microti, M. mungi, Dassie bacillus, Oryx bacillus and the attenuated $M$. bovis Bacille-Calmette-Guerin (BCG) vaccine strain. With the exception of BCG, these species are pathogenic and can cause tuberculosis (TB) in mammalian hosts (Kabongo-Kayoka et al., 2015).

Despite the fact that TB can be cured, this disease remains a worldwide public health threat due to the emergence of multi and extremely drug resistant strains and subsequent poor response to current antibiotics. One third of the world's population is infected with Mycobacterium tuberculosis (MTB) and is hence at risk of developing active TB. In the order of 9.6 million people every year develop TB and 1.5 million die from the disease. This includes 0.4 million TB deaths among HIV positive people (WHO, 2015). From the 9.6 million, only 12\% were HIV positive and it was also estimated that 480000 cases of multidrug-resistant TB (MDR-TB) have occurred in 2014. This confirms that TB alone is still a major challenge.

There is currently no effective vaccine to protect against TB. In humans, control of the disease relies heavily on detecting infectious cases and treating them for at least six months with a combination of antibiotics. The course of antibiotics involves the administration of first-line anti-TB drugs, which are combinations of isoniazid (INH), rifampicin (RIF), pyrazinamide and ethambutol for 2 months to kill the rapidly growing bacteria. The treatment is continued in the next 4 months with a combination of INH and RIF because of their sterilizing activity to eliminate bacilli which are dormant in the macrophages, or slow growers (Rivers and Mancera, 2008). Toxicity associated with these first-line drugs and the long duration of treatment has led 
to low patient compliance, giving rise to drug-resistant strains. Multidrug-resistant mycobacteria are resistant to INH and RIF whereas extremely drug-resistant mycobacteria are resistant to second-line drugs such as fluoroquinolones and to at least one injectable drug in addition to INH and RIF. Hence, there is a need to find new anti-tubercular agents with novel modes of actions (Chinsembu, 2016).

It is most likely that the emergence of resistant Mycobacterium isolates will continue in the future, exhausting the current range of effective antibiotics available. Therefore, new classes of anti-TB agents are urgently needed, and research projects seeking for alternative therapeutics have been encouraged. Natural resources have been explored to develop new antibiotics. Substances that can either inhibit the growth of pathogens or kill them while having little or no toxicity to host cells are considered good candidates for developing new antimicrobial drugs (Nguta et al., 2016).

Medicinal plants are used in many parts of the world to treat different ailments including TBrelated symptoms such as chest complaints, respiratory ailments, fever and coughing (McGaw et al., 2008). Relevant reviews of traditional medicinal use of plants in Africa are available (Hutchings et al., 1996; Kuete, 2010; Maroyi, 2013; Nguta et al., 2016; Stark et al., 2013; Van Wyk et al., 1997).

South Africa possesses the richest temperate flora in the world, with an estimated 24000 species and intraspecific taxa in 368 families-more than $10 \%$ of the world's vascular plant flora (Germishuizen and Meyer, 2003). There is much potential for discovery of structurally interesting metabolites with activity against Mycobacterium species from these plants. The existence of a strong cultural reliance on traditional medicines within South African communities justifies the importance of studying their safety and efficacy (Fennell et al., 2004). 
In a study conducted on Indian medicinal plants, Gautam et al., (2007) reported that with many of the plant species examined, there was a strong positive correlation between antimycobacterial activity and ethnomedicinal use for TB and TB-related diseases. Although this provides support for investigating plants customarily used in other cultures to treat symptoms relating to TB, other plants tested for antimycobacterial activity using indicator organisms such as M. smegmatis and M. bovis BCG should also be investigated (McGaw et al., 2008). Testing plant material not only against ATCC strains but against current isolates is crucial as these microorganisms are part of the changing environment harbouring emerging resistant strains.

The Anacardiaceae, cashew or Sumac is a tropical family that comprises flowering plant bearing fruits that are drupes and in some cases producing urushiol which is an irritant substance (Mabberley, 1997). The Anacardiaceae comprises several genera of economic importance namely Cashew (Anacardium occidentale), Mango (Mangifera indica), Poison Ivy (Toxicodendron radican, Smodingium argutum), Sumac (Searsia species), Smoke tree (Cotinus coggygria, Cotinus obovatus), Marula (Sclerocarya birrea), Yellow mombin (Spondias mombin, Spondias purpurea var. lutea), Cuachalalate (Amphipterygium adstringens) and Pistacia (Pistacia lentiscus, Pistacia integrrima). This family which belongs to the order of sapindales is represented by 77 genera and 600 species mostly distributed in tropical, subtropical, and temperate areas (Mabberley, 1997). Very few plant species of the Anacardiaceae family have been investigated for antimycobacterial activity. One of the objectives of this study was to investigate in vitro antimycobacterial activities as well as cytotoxicity of selected plant species from the Anacardiaceae family. These plants were selected mainly based on a preliminary broad antimicrobial screening (Pauw and Eloff, 2014). 
A summary on ethnobotanical use of the selected plant species from the Anacardiaceae family is presented in Table 1. Eight out of the 15 plants namely Lannea discolor, Loxostylis alata, Ozoroa mucronata, Ozoroa paniculosa, Protorhus longifolia, Searsia chirindensis, Searsia lancea and Sclerocarya birrea have antimicrobial properties mainly against Gram-negative and Gram-positive organisms. Three species (Searsia chirindensis, Searsia undulata and Smodingium argutum) have good anti-inflammatory activity. It would be useful to identify plant species with both antimycobacterial and anti-inflammatory efficacy as acute and chronic inflammations are induced during the course of tuberculosis (Volpe et al., 2006).

\section{Materials and Methods}

\subsection{Source of plant materials and extraction}

Leaves of the 15 plant species were collected in November 2009 from the Lowveld National Botanical Gardens in Nelspruit, the University of Pretoria Botanical Gardens and the Pretoria National Botanical Garden, South Africa in terms of a signed material transfer agreement. Leaves were kept in labelled bags with full identification and collection dates. Voucher specimens were kept in the Lowveld National Botanical Gardens (Nelspruit), HGWJ Schweickerdt Herbarium of the University of Pretoria and Phytomedicine Programme, University of Pretoria (Table 1). The leaves were air-dried at room temperature suspended in bags of net material in a ventilated room, ground to a fine powder in a Macsalab Mill (Model 200 LAB Eriez $\left.{ }^{\circledR}\right)$, Bramley, Johannesburg, South Africa) and stored in closed glass containers away from light until needed. Three grams of each plant were extracted in $30 \mathrm{~mL}$ of acetone, (technical grade, Merck, Darmstadt, Germany) in a $50 \mathrm{~mL}$ polypropylene centrifuge tube. Acetone was used as the extracting solvent due to its ability to extract a wide range of compounds and low toxicity on different microorganisms (Eloff, 1998a). The tube was 
vigorously shaken for $30 \mathrm{~min}$ on an orbital shaker, then centrifuged at $4000 \times \mathrm{g}$ for $10 \mathrm{~min}$ and the supernatant was filtered using Whatman No.1, 110mm diameter filter paper, before being transferred into pre-weighed glass containers (Eloff, 1998a). The extraction was repeated thrice on the same plant material and the solvent was removed by evaporation under a stream of air in a fume hood at room temperature to produce the dried extract. Extracts were made up to a concentration of $10 \mathrm{mg} / \mathrm{mL}$ in acetone for use in relevant tests.

\section{Insert table 1}

\subsection{Antimycobacterial activity}

The antimycobacterial activity of the acetone crude extracts of leaf powder was determined by using bioautography and the two-fold serial microdilution method. The pathogenic and rapidly growing mycobacteria were test microorganisms used for antimycobacterial activity.

\subsubsection{Pathogenic mycobacteria}

\subsubsection{Mycobacterium tuberculosis multidrug resistant isolates (MDR-TB)}

Two clinical isolates of multidrug resistant Mycobacterium tuberculosis (MDR-TB) were used. Both isolates were obtained from patients admitted to the MDR-TB ward at Tshepong hospital in Klerksdorp, North West province of South Africa in December 2012. The patients were a 34 year old female and an 18 year old male. Samples of sputum were submitted to the National Health Laboratory Services (NHLS) in Pretoria for culture in liquid medium and PCR/Line Probe Assay. Both isolates were resistant to isoniazid and rifampicin. 


\subsubsection{Mycobacterium bovis}

M. bovis cultures were isolated from field samples of cattle from herds that tested positive on tuberculination skin test during the period January 2009 to January 2011(Kabongo-Kayoka et al., 2015).

2.2.2 Rapidly growing mycobacteria

The Mycobacterium bovis BCG (Pasteur strain P1172) was obtained from Tuberculosis laboratory at Onderstepoort Veterinary Institute and the Mycobacterium tuberculosis H37Ra which is routinely used as reference material at NHLS was obtained from the American Type Culture Collection (ATCC) number 25177. Other reference strains used included a Mycobacterium aurum strain from the National Collection of Type cultures (NCTC), a culture collection of Public Health England, Mycobacterium aurum (NCTC 10437), Mycobacterium smegmatis (ATCC 1441) and M. fortuitum (ATCC 6841).

\subsubsection{Maintenance of cultures}

Fresh cultures were used in the relevant assays. The pathogenic isolates of Mycobacterium spp. were kept at room temperature on Lowenstein-Jensen (LJ) slants supplemented with glycerol or pyruvate in the case of the $M$. bovis BCG cultures and were used within a month. Prior to each assay, cultures were reactivated in liquid medium, Middlebrook 7H9, using MGIT 960 tubes which were incubated at $37^{\circ} \mathrm{C}$ in the BACTEC MGIT 960 instrument, in which they were automatically monitored each hour for fluorescence development for 42 days or until a positive signal developed. Bacterial suspensions from MGIT tubes were then subcultured on solid medium LJ slants with pyruvate for $M$. bovis and LJ slants with glycerol for M. tuberculosis. Löwenstein Jensen tubes were then incubated in a walk-in incubator at $37^{\circ} \mathrm{C}$ for 4 to 6 weeks. A stained Ziehl Neelsen smear was made from the sediment of the MGIT tube and the slant of LJ 
medium. Reference cultures of M. avium (ATCC 25291), M. bovis BCG and M. tuberculosis H37Ra (ATCC 25177) were used as positive controls.

The rapidly growing Mycobacterium species were maintained on Middlebrook 7H10 Agar prepared according to the manufacturer instructions (Merck) and kept in a fridge at $4^{\circ} \mathrm{C}$ until used within a month. Mycobacterium aurum and M. fortuitum were revived using Middlebrook 7H9 broth with glycerol and tween and supplemented with OADC (Oleic acid Albumin Dextrose Catalase) whereas $M$. smegmatis was revived using $\mathrm{MH}$ broth (Merck). Bacterial suspensions were inoculated on $\mathrm{MH}$ agar plates for M. smegmatis and the rest on Middlebrook 7H9 Agar. All agar plates were then incubated at $37{ }^{\circ} \mathrm{C}$ until colony growth was visible within 24 to72 hours depending on the growth rate of the specific mycobacterial species. The final density of 1 x $10^{5} \mathrm{CFU} / \mathrm{mL}$ used was confirmed after spreading an inoculum of $100 \mu \mathrm{L}$ of tenfold serial dilutions of the bacterial suspensions at McFarland No 1 onto Middlebrook 7H10 (M7H10) agar plates incubated at $37^{\circ} \mathrm{C}$ and counting colonies.

\subsubsection{Minimum inhibitory concentration (MIC) determination}

The MIC values were determined using the serial microplate method developed by Eloff (1998b) and slightly modified for mycobacteria by McGaw et al. (2008). The MIC value was the lowest concentration of the tested extract or sample inhibiting the growth of the Mycobacterium species under investigation. Mycobacterial suspensions were prepared from a pure culture of fresh colonies from solid medium and suspended in Middlebrook 7H9 (M7H9) liquid medium supplemented with $10 \%$ OADC. These colonies were transferred into a sterile screw capped tube containing $3 \mathrm{ml}$ of M7H9 broth and homogenized by placing the tube on a Vortex mixer for 5 minutes. After the larger particles had settled, the mycobacterial suspension was adjusted to McFarland no.1 turbidity standard by adding more broth (Lall and Meyer, 1999). 
The assay was performed using sterile 96-well microplates with rounded bottoms. The sample to be tested (plant extract, drug, fraction) was prepared at a concentration of $10 \mathrm{mg} / \mathrm{ml}$ before serial dilution. One hundred $\mu \mathrm{l}$ of M7H9 broth or MH broth was added to all the wells then $100 \mu \mathrm{l}$ of the sample to be tested were added in three adjacent column wells in the first row whereas other wells included standard drugs positive controls to assess bacterial growth, solvent control, broth to be inoculated and clean broth for sterility check. Two samples of crude extract and one standard drug were run per plate. A two fold serial dilution was carried out leaving $100 \mu \mathrm{l}$ of different concentrations of diluted tested samples in each well starting with a concentration of $2.5 \mathrm{mg} / \mathrm{ml}$ in the first wells. Then $100 \mu \mathrm{l}$ of the test bacterial suspension were added to all the wells except column 12 (negative control) containing pure broth to make sure that there was no contamination of the broth. Each dose was run in triplicate and the experiment repeated at least six times. The standard antibiotics (reference drugs) included ciprofloxacin, rifampicin, isoniazid and streptomycin starting with a concentration of $100 \mu \mathrm{g} / \mathrm{ml}$. The microplates were covered and sealed in plastic bags, placed in humid chambers to minimize the evaporation of the culture medium and incubated at $37^{\circ} \mathrm{C}$ for 24 hours (M. smegmatis), 48 hours (M. fortuitum) and 72 hours (M. aurum). For the pathogenic mycobacteria, microplates were incubated for a period of 7 to 15 days.

At the end of incubation, a volume of $40 \mu \mathrm{l}$ of $0.2 \mathrm{mg} / \mathrm{ml}$ of iodonitrotetrazolium chloride (INT) was added to each well, plates were incubated for 30 minutes or longer at $37^{\circ} \mathrm{C}$ and the development of colour observed. A coloured red-purple formazan or pink color indicated the reduction of INT by metabolizing organisms whereas a yellow color or decrease in color indicated the inhibition of bacterial growth (Eloff, 1998b). If the colour development was not strong enough for slow growing organisms, plates were incubated much longer and monitored. 
The correlation assessing the relationship between the MIC values of the 7 mycobacterial species used (Table 3) was calculated using Microsoft Excel 2010 software (Microsoft, Redmond, WA, USA).

\subsection{Thin Layer Chromatography (TLC) analysis and Bioautography}

Ten microliter from $10 \mathrm{mg} / \mathrm{mL}$ of relevant extracts (containing $100 \mu \mathrm{g}$ of extract) was loaded on aluminium-backed TLC plates (Merck silica gel F254) in lines of about $1 \mathrm{~cm}$ wide. The TLC plates were eluted in three different mobile solvent systems that included ethyl acetate/methanol/water (EMW) 10:1.35:1, chloroform/ethyl acetate/formic acid (CEF) 10:8:2 and benzene/ethanol/ammonia (BEA) 18:2:0.2 (Kotzé and Eloff, 2002). Chromatograms were examined under ultraviolet light at wavelengths of 254 and $366 \mathrm{~nm}$ to visualize UV active compounds that fluoresce and might not be visible after vanillin spray; the plates were then sprayed with a solution made of $0.1 \mathrm{~g}$ vanillin in $28 \mathrm{ml}$ of methanol and $1 \mathrm{ml}$ of sulphuric acid (vanillin-Methanol-sulphuric acid) and heated at $110^{\circ} \mathrm{C}$ with a heat gun for colour development and visualization of UV inactive compounds present in the plant extract. More than 10 compounds of different polarities were observed. These compounds were very close to each other in both the solvent systems BEA and CEF. In general, the active plants had different activities against different Mycobacteria. Active compounds included both polar and non-polar compounds based on the Rf values determined in bioautography. In the non-polar solvent BEA, the non- polar compounds travelled some distance up the plate with clear zone of inhibition on plates sprayed with different Mycobacteria species whereas in the polar solvent system EMW, non- polar compounds were pushed towards the solvent front and polar compounds off the baseline. The CEF solvent system led to a better separation of some compounds (B in Figure 1). 
For bioautography, only the rapidly growing organisms were used, namely $M$. aurum, $M$. fortuitum and M. smegmatis, because the pathogenic mycobacteria present a high biohazard risk if handled in a spray format. Aerosols of pathogenic species increase risk of possible contamination of the environment and human exposure. Duplicate chromatograms prepared as described above were left uncovered in a dark place and air dried until solvents were completely evaporated for at least 24 hours or overnight. A saturated bacterial culture was centrifuged at $3000 \mathrm{x}$ g for $10 \mathrm{~min}$ and the pellet resuspended in fresh appropriate liquid growth medium and prepared at McFarland No 1. The TLC plates were then sprayed with active bacterial suspension (18 to 72 hour old cultures depending on the growth rate of the particular Mycobacterium species) until completely moist using a glass spray gun linked to a vacuum pump. The moist plates were incubated at $37{ }^{\circ} \mathrm{C}$ in a humidified chamber under $100 \%$ relative humidity for 24 hours for Mycobacterium smegmatis, 48 hours for M. fortuitum and 72 hours for M. aurum. The plates were then sprayed with $2 \mathrm{mg} / \mathrm{mL}$ of INT (Sigma, Johannesburg, South Africa) in distilled water and incubated for a further $30 \mathrm{~min}$ to few hours until the development of clear zones against a purple-red background. The emergence of purple-red colour resulting from the reduction of INT into formazan indicated the presence of viable microorganisms whereas clear zones against the purple-red background indicated inhibition of mycobacterial growth indicating the Rf values of antimycobacterial compounds separated on the thin layer chromatography plates (Hamburger and Cordell, 1987).

\subsection{In vitro cytotoxicity assay and selectivity index}

The cytotoxicity of crude acetone extracts from plants with good MIC values and clear zones of inhibition on bioautography was determined using a tetrazolium-based colorimetric assay, 3-(4, 5-dimethylthiazol)-2, 5-diphenyl tetrazolium bromide (MTT assay) described by (Mosmann, 
1983) and slightly modified by (McGaw et al., 2007). Vero African Monkey kidney cells were obtained from the cell culture collection of the Department of Tropical Diseases (University of Pretoria), cancer liver cells (hepatoma C3A) purchased from the American Type Culture Collection (ATCC), Manassas, USA, CRL-10741 and murine macrophage (RAW 264.7) cells purchased from ATCC, ATCC ${ }^{\circledR}$ TIB71 ${ }^{\mathrm{TM}}$ were used. Cells were cultured in Minimal Essential Medium Eagle with L-Glutamine (EMEM) (BioWhittaker, Lonza, Belgium) supplemented with 0.1\% gentamicin (Genta50) (Virbac, Centurion, South Africa) and 5\% foetal calf serum (Highveld Biological, Sandton, Modderfontein, South Africa) for Vero cells and 5\% sodium pyruvate (Adcock Ingram, Midrand, South Africa) and 10\% of foetal calf serum were added for C3A cells. For C3A and Vero cells, a 5 day old confluent culture in $75 \mathrm{~cm}^{2}$ flasks were harvested and centrifuged at $200 \times g$ for 2 min, and the pellet resuspended in growth medium to a density of $0.1 \times 10^{6}$ cells/mL whereas RAW 264.7 cells were mechanically scraped, plated at a density of $4 \times 10^{5}$ cells/mL onto 96-well plates containing $100 \mu \mathrm{L}$ of Dulbecco's Modified Eagle Medium (DMEM) (BioWhittaker, Lonza, Belgium) and incubated in a $37^{\circ} \mathrm{C}, 5 \% \mathrm{CO}_{2}$ incubator for $24 \mathrm{~h}$ prior to exposure. The following procedure was the same for all the different types of cells. A sterile 96-well microplate was used; cell suspension $(100 \mu \mathrm{L})$ was added into each well of columns 2-11. Columns 1 and 12 were used as blanks with $200 \mu \mathrm{l}$ of growth medium to minimize the "edge effect" and maintain humidity. The plates were incubated for $24 \mathrm{~h}$ at $37{ }^{\circ} \mathrm{C}$ in a $5 \% \mathrm{CO}_{2}$ incubator and cells were observed until they reached the exponential phase of growth. The cells were then exposed to different concentrations of the extract sample as well as to Doxorubicin Hydrochloride (Adriblastina CSV, Pfizer, Johannesburg, South Africa) as positive control and acetone as negative control. From a concentration of $100 \mathrm{mg} / \mathrm{ml}$ of the extract sample, different concentrations using growth medium as a diluent were prepared, 
namely $1,0.75,0.5,0.25,0.1,0.075,0.05$ and $0.025 \mathrm{mg} / \mathrm{ml}$. The microplates were then incubated for $48 \mathrm{~h}$. After this period of incubation, the medium was removed from the wells containing the cells using a multichannel pipette attached to a pump via a plastic tube; cells were rinsed with $200 \mu$ l phosphate buffered saline (PBS, Sigma-Aldrich, Johannesburg, South Africa) and replaced with $200 \mu \mathrm{L}$ of fresh medium. Then thirty (30 $\mu \mathrm{l})$ of a $5 \mathrm{mg} / \mathrm{ml}$ solution of 3-(4, 5dimethylthiazol)-2, 5-diphenyl tetrazolium bromide (Sigma-Aldrich, Johannesburg, South Africa) in PBS was added to each well. The plates were incubated for a further $4 \mathrm{~h}$ at $37^{\circ} \mathrm{C}$ in the $\mathrm{CO}_{2}$ incubator. After incubation, the medium was carefully removed using the same multichannel pipette connected to a pump without disturbing the MTT formazan crystals in each well. Then $50 \mu \mathrm{l}$ of dimethyl sulfoxide (DMSO) was added to each well to dissolve the MTT crystals absorbance values were read immediately using a microplate reader (BioTek Synergy HT, Analytical and Diagnostic Products, Johannesburg, South Africa) at a wavelength of 570 nm. Columns 1 and 12 were used as blank. The different concentrations were tested in quadruplicate and the assay was repeated at least three times. The $\mathrm{LC}_{50}$ values were calculated as the concentration of plants extracts where $50 \%$ of cells were still viable compared to untreated cells in columns 2 and 11 . The selectivity index of the active plants was calculated using $\mathrm{LC}_{50}$ values divided by MIC values ( $\left.\mathrm{LC}_{50} / \mathrm{MIC}\right)$.

\subsection{Statistical analysis}

All experiments were conducted in triplicate and values expressed as mean \pm standard deviation. For the MIC values, re-evaluation of the growth inhibition was conducted where a wide variation within the three experiments was noticed. The relationship between the different mycobacterial MIC values was calculated using the Pearson’s correlation coefficient (r).

\section{Results and Discussion}




\subsection{Acetone extract plant yield}

The extraction yield of the plant species ranged from 0.8 to $18.8 \%$ (Table 2). The highest percentage was observed with Searsia magaliesmontana (18.8\%) followed by Searsia undulata (12.5\%) and Protorhus longifolia (8.3\%). Heeria argentea had the lowest yield of $0.8 \%$. The

extraction yield and bioactivities of extracts using different extractants vary strongly (Kotzé and Eloff, 2002), hence the choice of acetone in this study.

\section{Insert table 2}

\subsection{Biological activity of extracts}

Bioautography of extracts using two (M. aurum and $M$. fortuitum) out of the three rapidly growing mycobacteria led to strong, clear zones of inhibition. This also corresponded with low MIC values obtained ranging from 0.05 to $0.1 \mathrm{mg} / \mathrm{ml}$.

Extracts with MIC values $\leq 0.1 \mathrm{mg} / \mathrm{mL}$ were considered to have significant activity; moderate activity was between 0.1 and $0.625 \mathrm{mg} / \mathrm{mL}$ and weak or poor activity (resistant) with MICs $>0$. $625 \mathrm{mg} / \mathrm{mL}$ (Kuete, 2010). All 15 plant extracts had good to moderate antimycobacterial activity against rapidly growing and pathogenic mycobacteria ranging from 0.05 to 0.590 $\mathrm{mg} / \mathrm{mL}$. Searsia undulata extracts had significant antimycobacterial activity with the lowest MIC value of $0.07 \mathrm{mg} / \mathrm{mL}$ for $M$. aurum and $M$. fortuitum followed by $M$. smegmatis with MIC of $0.09 \mathrm{mg} / \mathrm{mL}$. Protorhus longifolia extracts also had significant antimycobacterial activity against all three non-tuberculous mycobacteria with MIC values of $0.11 \mathrm{mg} / \mathrm{mL}$ for both $M$. aurum and $M$. fortuitum and $0.07 \mathrm{mg} / \mathrm{mL}$ for M. smegmatis. Searsia lancea, Sclerocarya birrea and Harpehyllum caffrum had moderate activity of $0.420 \mathrm{mg} / \mathrm{mL}, 0.520 \mathrm{mg} / \mathrm{mL}$ and 0.590 $\mathrm{mg} / \mathrm{mL}$ against $M$. aurum respectively whereas the same plant species had moderate activity with low MIC values of 0.21 and $0.11 \mathrm{mg} / \mathrm{mL} ; 0.13$ and $0.21 \mathrm{mg} / \mathrm{mL}$ and 0.21 and $0.11 \mathrm{mg} / \mathrm{mL}$ against 
M. fortuitum and M. smegmatis respectively. Searsia undulata had significant activity against all mycobacteria including $M$. bovis and MDR-TB isolates with MIC ranging from 0.05 to 0.11 $\mathrm{mg} / \mathrm{mL}$, and the lowest value of $0.05 \mathrm{mg} / \mathrm{ml}$ against M. tuberculosis ATCC strain H37Ra.

Positive correlation was observed between the pathogenic isolates, M. bovis and MDR-TB, with M. fortuitum with (r) coefficient correlation values of 0.62 and 0.65 respectively whereas negative correlation with value of -0.005 was observed with M. aurum. Good correlation was observed between ATCC strain, H37Ra and rapidly growing mycobacteria with values of 0.92 , 0.87 and 0.37 for $M$. fortuitum, M. aurum and $M$. smegmatis respectively and the highest coefficient correlation value of 0.98 between $M D R-T B$ isolate with the pathogenic M. bovis isolate (Table 3)

\section{Insert table 3}

The total activity value of an extract from a plant indicates which species could be the candidates for organic production of active extracts for use by communities because it takes into account not only the MIC of the extract but also the yield of the extract. By dividing the extraction yield in $\mathrm{mg} / \mathrm{g}$ by the MIC in $\mathrm{mg} / \mathrm{ml}$ the total activity is calculated in $\mathrm{ml} / \mathrm{g}$ (Eloff, 2000). This provides the volume in $\mathrm{ml}$ that the extract from $1 \mathrm{~g}$ of dry material can be diluted and still kills the pathogen. Searsia undulata had the lowest MIC values (significant activity) with the highest \% yield and highest total activity of $5357 \mathrm{~mL} / \mathrm{g}$ on $M$. fortuitum and $2885 \mathrm{~mL} / \mathrm{g}$ on MDR-TB followed by Protorhus longifolia showing the highest total activity of $3557 \mathrm{~mL} / \mathrm{g}$ on $M$. smegmatis and $2264 \mathrm{~mL} / \mathrm{g}$ on MDR-TB. The results of total activity using rapidly growing mycobacteria are not shown due to limitation on number of tables. These two plants are the best candidates for further investigation due to their low cytotoxicity and more than 30 antimycobacterial compounds observed using bioautography. In addition, (Mosa et al., 2014) 
reported that Protorhus longifolia had antibacterial activity towards resistant clinical isolates of Gram negative (Pseudomonas aeruginosa) and Gram positive (Staphylococcus aureus) whereas Searsia undulata has been used to treat chest cold (Hutchings et al., 1996). Specific antimicrobials targeting Gram negative and Gram positive bacteria are useful but this does not eliminate the need for broader spectrum antimicrobials. However, other plants with moderate activity are worthy of investigation as studies have shown that there is synergy among different compounds within an extract and once fractionated, different fractions/compounds might be more active than the crude extract (Awouafack et al., 2013). 
3.3 Bioautography and thin layer chromatography analysis

Although all selected plant species had significant to moderate activity against all Mycobacterium species tested, plants showing at least MIC below $0.1 \mathrm{mg} / \mathrm{mL}$ or close to 0.1 $\mathrm{mg} / \mathrm{mL}$ for any of the mycobacteria tested were selected to be investigated by bioautography. Five plants were selected namely Heeria argentea, Lannea discolor, Protorhus longifolia, Searsia undulata and Sclerocarya birrea. Only three plant species, Harpephyllum caffrum, Protorhus longifolia and Searsia undulata, had one or more clear zones of inhibition after spraying with M. aurum or M. fortuitum. Searsia undulata was the only species to show clear zones of inhibition with both $M$. aurum and $M$. fortuitum with more compounds visible with $M$. aurum. Using bioautography, M. aurum was the best indicator of antimycobacterial activity followed by M. fortuitum. Low MIC value might not always correlate with visualization of clear zones of inhibition due to the nature of separated compounds on the TLC plate, which may be volatile or experience loss of activity due to the separation of compounds that were acting in synergy in the crude extract. The crude extract of Searsia undulata had several active compounds against $M$. aurum - potentially more than ten compounds as some compounds were very close to each other in terms of $\mathrm{Rf}$ values ranging from 0.05 to 0.98 in the different solvent systems BEA, CEF and EMW (results not shown). Based on the MIC values and bioautogram patterns, the same plant extract have shown different activities towards different mycobacteria species. M. smegmatis also had some low MIC values with few or no visible zones of inhibition. The BEA and CEF solvent systems gave the best separation of compounds at this initial stage (Figure 1).

\section{Insert Figure 1}




\subsection{Cytotoxicity assay}

Most drugs or other substances are metabolised in the liver and excreted by the kidney. Mycobacterial species causing tuberculosis multiply and hide in macrophages. Therefore, three cell lines were selected to represent these organs namely Vero monkey kidney, human liver hepatoma (C3A) and mouse macrophage cells (RAW 264.7). Cancer cells are abnormal cells, and substances showing cytotoxicity to C3A cells and low cytotoxicity to the Vero cells may also be good candidates for further investigation as anticancer preparations. Cell-based in vitro toxicity assays are performed at an early stage of the drug development process in order to remove high-risk materials. Plants extracts showing sensitivity to cell lines with $\mathrm{LC}_{50}$ values $>0.1 \mathrm{mg} / \mathrm{mL}$ are considered not cytotoxic in terms of searching for anticancer compounds (Kuete, 2010). Crude extracts (Heeria argentea, Lannea discolor, Protorhus longifolia, Searsia undulata and Sclerocarya birrea) with good antimycobacterial activity (from significant to moderate) and those that showed visible zones of inhibition on bioautograms were selected for cytotoxicity testing. All crude extracts tested showed low toxicity against all three cell lines (C3A, Vero cells and RAW (264.7) except Searsia undulata that had moderate toxicity to C3A cells with $\mathrm{LC}_{50}$ of $0.034 \mathrm{mg} / \mathrm{mL}$. This deserves further investigation as source of anticancer substance as C3A cells are cancer cells with abnormal metabolic activity. The S. undulata extract had $\mathrm{LC}_{50}$ of 0.50 and $0.12 \mathrm{mg} / \mathrm{mL}$ on Vero cells and RAW cells respectively with good selectivity indexes of 7.08 on Vero cells and more than 1 on RAW cells for non-tuberculous and MDR-TB mycobacteria. Protorhus longifolia had an $\mathrm{LC}_{50}$ of $0.62 \mathrm{mg} / \mathrm{mL}$ on C3A cells, 0.88 $\mathrm{mg} / \mathrm{mL}$ on Vero cells and $>1 \mathrm{mg} / \mathrm{mL}$ for RAW cells with highest selectivity index on Vero cells of 12.6 for M. smegmatis followed by 8.02 for M. aurum, M. fortuitum and MDR-TB. Plant extracts with SI values less than1 mean that the extracts are relatively less toxic to the bacteria 
and more toxic to the mammalian cells (Eloff, 2000). Therefore, extracts with SI $>1$ may be relatively safer to use in vivo (not accounting for pharmacokinetic parameters) as they are less toxic to mammalian cells but more toxic to the pathogens. The selectivity indexes, especially of P. longifolia with SI $=12$. 6 could be considered as very promising as a good therapeutic index for a remedy or drug should be $\geq 10$ (Caamal-Fuentes et al., 2011). It is also worth noting that efficacy “in vitro" might differ from efficacy "in vivo" due to different parameters influencing pharmacodynamics and pharmacokinetic of drugs administered by different routes to humans and animals. In this study, Protorhus longifolia and Searsia undulata had the highest selectivity index against the three rapidly growing mycobacteria and pathogenic mycobacteria and the highest total activity. These rapidly growing species had the highest total activity of $5357 \mathrm{~mL} / \mathrm{g}$ for S. undulata and $3557 \mathrm{~mL} / \mathrm{g}$ for $P$. longifolia which indicates the volume to which the extract from $1 \mathrm{~g}$ can be diluted and still inhibit the growth of mycobacteria. It is also worth noting that the leaves of $S$. undulata are chewed by Khoi people to treat chest cold, indicating a low toxicity. The mode of administration and interaction with other factors in" vivo" must be considered when assessing toxicity.

\section{Insert Table 4}

\section{Conclusion}

This is the first report on antimycobacterial activity of these tree species from the Anacardiaceae family in Africa. Acetone leaf crude extracts of all the selected plants have shown significant to moderate antimycobacterial activity. Harpephyllum caffrum, Lannea discolor, Protorhus longifolia, Searsia undulata and Sclerocarya birrea susbsp. caffra had good antimycobacterial activity and low cytotoxicity. Some rapidly growing mycobacteria may be used as indicators for detecting good antimycobacterial activity of plant extracts against pathogenic mycobacteria 
based on the correlation of MIC values. The best indicators of antimycobacterial activity on MIC and bioautography were M. aurum followed by M. fortuitum. P. longifolia and S. undulata had good antimycobacterial activity against all mycobacterial species. Low cytotoxicity was observed on Vero cells and RAW cells. Searsia undulata was cytotoxic to hepatoma cells and could be investigated further as a source of potential anticancer substances. Adding to results obtained from the bioautography, MIC values and cytotoxicity as well as ethnobotanical use, $P$. longifolia and S. undulata had good potential antimycobacterial activity worthy of further investigation. The ethnobotanical use of chewing S. undulata leaves by Khoi people to treat chest colds is interesting and the antimicrobial activity of leaf extracts of this species supports this use although further study is necessary to validate this supposition. Isolation and characterization of compounds from these highly promising species are underway.

\section{Acknowledgments}

The research protocol was approved by the Ethical Research Committee at University of South Africa (UNISA) Reference number: CAES/087 and the Department of Agriculture, Forestry and Fisheries under section 20. UNISA and National Research Foundation (NRF grant No: 66141 and 86458) provided funding to support this study.

\section{Conflict of interest}

The authors have declared no conflict of interest. 


\section{REFERENCES}

Ahmed AS, McGaw LJ, Moodley N, Naidoo V, Eloff JN. 2014. Cytotoxic, antimicrobial, antioxidant, antilipoxygenase activities and phenolic composition of Ozoroa and Searsia species (Anacardiaceae) used in South African traditional medicine for treating diarrhoea. $S$ Afr J Bot 95: 9-18.

Awouafack MD, McGaw LJ, Gottfried S, Mbouangouere R, Tane P, Spiteller M, Eloff JN. 2013. Antimicrobial activity and cytotoxicity of the ethanol extract, fractions and eight compounds isolated from Eriosema robustum (Fabaceae). BMC Complement Altern Med 13: 289.

Caamal-Fuentes E, Torres-Tapia L, Simá-Polanco P, Peraza-Sánchez SR, Moo-Puc R. 2011. Screening of plants used in Mayan traditional medicine to treat cancer-like symptoms. $J$ Ethnopharmacol 135: 719-724.

Chinsembu KC. 2016. Tuberculosis and nature's pharmacy of putative anti-tuberculosis agents. Acta Trop 153: 46-56.

Eloff JN. 2000. On expressing the antibacterial activity of plant extracts - a small first step in applying scientific knowledge to rural primary health care. S Afr J Sci. 96: 116-118.

Eloff JN. 1998a. Which extractant should be used for the screening and isolation of antimicrobial components from plants? J Ethnopharmacol 60: 1-8.

Eloff JN. 1998b. A sensitive and quick microplate method to determine the minimal inhibitory concentration of plant extracts for bacteria. Planta Med 64: 711-713.

Fennell CW, Lindsey KL, McGaw LJ, Sparg SG, Stafford GI, Elgorashi EE, Grace OM, Staden J. 2004. Assessing African medicinal plants for efficacy and safety: pharmacological screening and toxicology. J Ethnopharmacol 94: 205-217.

Gautam R, Saklani A, Jachak SM. 2007. Indian medicinal plants as a source of antimycobacterial agents. J Ethnopharmacol 110: 200-234.

Germishuizen G, Meyer NL. 2003. Plants of southern Africa: an annotated checklist. Plants South. Africa an Annot. Checkl., Strelitzia 14.

Hamburger MO, Cordell GA. 1987. A direct bioautographic TLC assay for compounds possessing antibacterial activity. J Nat Prod 50: 19-22.

Hutchings A, Scott AH, Lewis G, Cunningham A. 1996. Zulu Medicinal Plants. An Inventory. University of Natal Press. Scottsville: Pietermaritzburg.

Kabongo-Kayoka P, Obi CL, Nakajima C, Suzuki Y, Hattori T, Eloff JN, Wright J, Mbelle N, McGaw LJ. 2015. Novel Mycobacterium avium Complex Species Isolated From Black Wildebeest (Connochaetes gnou) in South Africa. Transbound Emerg Dis. doi:10.1111/tbed.12460.

Kotzé M, Eloff JN. 2002. Extraction of antibacterial compounds from Combretum 
microphyllum (Combretaceae). S Afr J Bot 68: 62-67.

Kuete V. 2010. Potential of Cameroonian plants and derived products against microbial infections: a review. Planta Med 76: 1479-1491.

Lall N, Meyer JJ. 1999. In vitro inhibition of drug-resistant and drug-sensitive strains of Mycobacterium tuberculosis by ethnobotanically selected South African plants. J Ethnopharmacol 66: 347-354.

Mabberley DJ. 1997. The Plant-Book: A Portable Dictionary of the Vascular Plants. Cambridge University Press.

Maroyi A. 2013. Traditional use of medicinal plants in south-central Zimbabwe: review and perspectives. J Ethnobio Ethnomed 9:31.

McGaw LJ, Lall N, Meyer JJ, Eloff JN. 2008. The potential of South African plants against Mycobacterium infections. J Ethnopharmacol 119: 482-500.

McGaw LJ, Steenkamp V, Eloff JN. 2007. Evaluation of Athrixia bush tea for cytotoxicity, antioxidant activity, caffeine content and presence of pyrrolizidine alkaloids. $J$ Ethnopharmacol 110: 16-22.

Mosa RA, Nhleko ML, Dladla TV, Opoku AR. 2014. Antibacterial activity of two triterpenes from stem bark of Protorhus longifolia. J Med Plants Res 8: 686-702.

Mosmann T. 1983. Rapid colorimetric assay for cellular growth and survival: application to proliferation and cytotoxicity assays. J Immunol Methods 65: 55-63.

Nguta JM, Appiah-Opong R, Nyarko AK, Yeboah-Manu D, Addo PGA, Otchere I, Kissi-Twum A. 2016. Antimycobacterial and cytotoxic activity of selected medicinal plant extracts. $J$ Ethnopharmacol 182:10-15.

Ojewole JAO. 2008. Anticonvulsant effect of Rhus chirindensis (Baker F.) (Anacardiaceae) stem-bark aqueous extract in mice. J Ethnopharmacol 117: 130-135.

Pauw E, Eloff JN. 2014. Which tree orders in southern Africa have the highest antimicrobial activity and selectivity against bacterial and fungal pathogens of animals? BMC Complement Altern Med 14: 317-325.

Rivers EC, Mancera RL. 2008. New anti-tuberculosis drugs in clinical trials with novel mechanisms of action. Drug Discov Today 13: 1090-1098.

Stark TD, Mtui DJ, Balemba OB. 2013. Ethnopharmacological survey of plants used in the traditional treatment of gastrointestinal pain, inflammation and diarrhea in Africa: future perspectives for integration into modern medicine. Animals 3: 158-227.

Van Wyk BE, Van Oudtshoorn B, Gericke N. 1997. Medicinal Plants of South Africa. Briza Publications: South Africa.

Volpe E, Cappelli G, Grassi M, Martino A, Serafino A, Colizzi V, Sanarico N, Mariani F. 2006. Gene expression profiling of human macrophages at late time of infection with 
Mycobacterium tuberculosis. Immunology 118: 449-460.

World Health Organization (WHO) Report: Global tuberculosis report. 2015. http:// www.who.int/tb/publications/global-report/2015 (accessed 14 November 2015). 
Table 1 Ethnomedicinal use and known isolated compounds of selected species of the Anacardiaceae family

\begin{tabular}{|c|c|c|c|c|c|c|}
\hline Botanical names & Common names & Voucher number & Plant part used & Ethnomedicinal use & $\begin{array}{l}\text { Phytochemical constituents } \\
\text { /pharmacological activities }\end{array}$ & References \\
\hline Harpephyllum caffrum & $\begin{array}{l}\text { Wild plum (Eng); } \\
\text { wildepruim (Afr.); } \\
\text { Umgwenya (X, Z) }\end{array}$ & PRU2583 & Bark, leaves and roots & $\begin{array}{l}\text { Purifying blood, skin } \\
\text { problems } \\
\text { scarifications around } \\
\text { sprains and fractures } \\
\text { and leg paralysis due } \\
\text { to poison }\end{array}$ & $\begin{array}{l}\text { Polyphenolic and } \\
\text { flavonoids/anticonvulsant }\end{array}$ & $\begin{array}{l}\text { Hutchings et al., 1996; } \\
\text { Van Wyk et al., } 1997\end{array}$ \\
\hline Heeria argentea & $\begin{array}{l}\text { Cape Rockwood, } \\
\text { Wild Apricot (Eng.); } \\
\text { Kliphout (gom) and } \\
\text { Wilde-Naelboom } \\
\text { (Afr.) }\end{array}$ & PMDN751 & Gum & $\begin{array}{l}\text { Gum mixed with } \\
\text { sweet oil used as } \\
\text { plaster for burns, } \\
\text { wounds, tender } \\
\text { nipples and } \\
\text { powdered herb with } \\
\text { fat applied to ulcers }\end{array}$ & - & Hutchings et al., 1996 \\
\hline Lannea discolor & $\begin{array}{l}\text { Live long (Eng); } \\
\text { Dikbas (Afr.); } \\
\text { Isiganganyane (Z) }\end{array}$ & PMDN565 & Bark, roots and leaves & $\begin{array}{l}\text { Treatment of } \\
\text { diarrhoea, } \\
\text { abscesses, infertility } \\
\text { in women, } \\
\text { menorrhagia, } \\
\text { gonorrhea, swollen } \\
\text { legs, whooping } \\
\text { cough, counteract } \\
\text { effect of lightning and } \\
\text { sore eyes }\end{array}$ & Phenolic flavone/ antimicrobial & $\begin{array}{l}\text { Hutchings et al., 1996; } \\
\text { Maroyi, 2013; Van Wyk } \\
\text { et al., } 1997\end{array}$ \\
\hline
\end{tabular}


Loxostylis alata

Ozoroa Paniculosa

Protorhus longifolia

Searsia chirendensis

Searsia lancea
Wild pepper tree,

tarwood (Eng);

teerhout, tierhout

Afr); Ufutho, ufuthu

(Z)

No common names associated with this

axon yet. Mvunda-

Jukunu in Tanzania

\section{NEL71/1993 \\ Leaves and roots}

Red resin tree

(Eng.)

Red beech (Eng),

rooiboekenhout

(Afr.); umkhomizo

unhlangothi (Z)

Red currant (Eng.);

Bostaaibos (Afr.)

umHlabamvubu (Z)

PMDN333

Stem Bark
Used at childbirth boost immunity

Phenolic lipids, cardanol and ginkgolic acid; lupeol 1 and Bsitosterol 2; antimicrobials

Diarrhoea, dysentery, Anacardic acid; flavonoids, stomach troubles,

phenols, tannins/antimicrobia

gonorrhea, bilharzia

and antidote for

snake bite

Diarrhoea and abdominal pain

Flavonoids, phenols, tannins

Anacardic acid, ginkgoic acid and triterpenes/antimicrobial

Heartburn, bleeding

from stomach,

depilatories,

Heartwater,

dysentery and

diarrhoea in cattle

Heart, stomach

ailments, diarrhoea,

strengthen the body

stimulate circulation

rheumatism and

mental disturbances

Saponins, tannins triterpenoids

and flavonoids/ Inflammatory,

analgesic and anticonvulsant

penes, lanostery

erpen/antimicrobial,

Antihyperlipidemic and

antihyperglycemic
Ahmed et al., 2014

Ahmed et al., 2014

Stark et al., 2013

Mosa et al., 2014
Karee (Eng.),

umHlakotshane $(X)$
PMDN750
Diarrhoea,

gallsickness
Flavonoids and

tannins/antimicrobia 


\begin{tabular}{|c|c|c|c|c|c|c|}
\hline Searsia leptodictya & $\begin{array}{l}\text { Mountain karee } \\
\text { (Eng.), bergkaree } \\
\text { (Afr.) Motshotlwane } \\
\text { (Tsw) }\end{array}$ & NEL94/1969 & Bark, leaves and roots & Diarrhoea and pain & Phenols, tannins and flavonoids & $\begin{array}{l}\text { Ahmed et al., 2014; } \\
\text { Stark et al., } 2013\end{array}$ \\
\hline $\begin{array}{l}\text { Searsia magaliesmontana } \\
\text { susbsp }\end{array}$ & - & NEL68/1997 & - & - & - & - \\
\hline Searsia pyroides & $\begin{array}{l}\text { Wildcurrant (Eng.); } \\
\text { Brandtaaibos, (Afr.); } \\
\text { Inhlokoshiyane (Z) }\end{array}$ & PMDN570 & $\begin{array}{l}\text { Leaves, roots and stem } \\
\text { bark }\end{array}$ & $\begin{array}{l}\text { Treatment of epilepsy } \\
\text { and cough medicine }\end{array}$ & Flavonoids bichalcones & Maroyi, 2013 \\
\hline Searsia undulata & $\begin{array}{l}\text { T'kuni (khoi); Kuni } \\
\text { bush, (Eng.); } \\
\text { Koenibos (Afr.) }\end{array}$ & PRU120031 & Bark, leaves and roots & $\begin{array}{l}\text { Post-parturient } \\
\text { problems and } \\
\text { treatment for chest } \\
\text { colds }\end{array}$ & $\begin{array}{l}\text { Apigenin 7,4'-dimethyl ether, } \\
\text { flavone/ Anti-inflammatory }\end{array}$ & Hutchings et al., 1996 \\
\hline Sclerocarya birrea susbsp caffra & $\begin{array}{l}\text { Cider tree, marula } \\
\text { (Eng.); Maroela } \\
\text { (Afr.); Umganu (Z) }\end{array}$ & NEL103/1967 & Bark, leaves and roots & $\begin{array}{l}\text { Diarrhoea, dysentery, } \\
\text { pain, stomach } \\
\text { problems, fever, } \\
\text { cough, malaria, tonic, } \\
\text { diabetes and sore } \\
\text { eyes }\end{array}$ & $\begin{array}{l}\text { Gallotannins, Flavonoids, } \\
\text { epicatechin, alkaloids, } \\
\text { triterpenoids and vitamin c } \\
\text { IAnticonvulsants; antidiarrhoeal, } \\
\text { antidiabetic, anti-inflammatory, } \\
\text { antimicrobial and antioxidant }\end{array}$ & $\begin{array}{l}\text { Maroyi, 2013; Stark et } \\
\text { al., 2013; Van Wyk et } \\
\text { al., } 1997\end{array}$ \\
\hline Smodingium argutum & $\begin{array}{l}\text { African poison ivy } \\
\text { (Eng.); Pynbos } \\
\text { (Afr.); Umthomvane } \\
\text { (Z) }\end{array}$ & PMDN188 & Bark, leaves and roots & $\begin{array}{l}\text { Diarrhoea and } \\
\text { diabetes }\end{array}$ & $\begin{array}{l}\text { Catechols, phenolic lipids } \\
\text { (cardanol and ginkgolic acid) } \\
\text { IAntidiarrhoeal, hypoglycaemic } \\
\text { effects and anti-inflammatory }\end{array}$ & Hutchings et al., 1996 \\
\hline
\end{tabular}


Table 2. Minimal inhibitory concentration (MIC in $\mathrm{mg} / \mathrm{ml}$ ) and total activity (TA in $\mathrm{ml} / \mathrm{g}$ ) of acetone leaf extract from 15 plants of the Anacardiaceae family against $M$. bovis and $M$. tuberculosis

\begin{tabular}{|c|c|c|c|c|c|c|c|c|c|c|c|}
\hline & & & & MBCG & & $\mathrm{H} 37 \mathrm{Ra}$ & & MBfield & & MDR-Tb & \\
\hline Plant species & Voucher number & Extraction yield & Mass yield (mg) & $M I C \pm S D$ & TA & $M I C \pm S D$ & TA & $M I C \pm S D$ & TA & $M I C \pm S D$ & $\mathrm{TA}$ \\
\hline Harpephyllum caffrum & PRU2583 & 4.6 & 138 & $0.11 \pm 0.05$ & 1255 & $0.16 \pm 0$ & 863 & $0.13 \pm 0.05$ & 1062 & $0.21 \pm 0.09$ & 657 \\
\hline Heeria argentea & PMDN 751 & 0.8 & 24 & $0.26 \pm 0.09$ & 92 & $0.52 \pm 0.18$ & 46 & $0.26 \pm 0.09$ & 92 & $0.21 \pm 0.09$ & 114 \\
\hline Lannea discolour & PMDN 565 & 5.7 & 171 & $0.11 \pm 0.05$ & 1555 & $0.11 \pm 0.05$ & 1555 & $0.21 \pm 0.09$ & 814 & $0.52 \pm 0.18$ & 329 \\
\hline Loxostylis alata & PRU3526 & 4.9 & 147 & $0.21 \pm 0.08$ & 700 & $0.24 \pm 0.08$ & 613 & $0.52 \pm 0.18$ & 283 & $0.52 \pm 0.18$ & 283 \\
\hline Ozoroa mucronata & NEL71/1993 & 1.7 & 51 & $0.625 \pm 0$ & 82 & $0.625 \pm 0$ & 82 & $0.51 \pm 0.17$ & 100 & $0.51 \pm 0.17$ & 100 \\
\hline Ozoroa paniculata & PMDN 568 & 7.7 & 231 & $0.52 \pm 0.18$ & 444 & $0.52 \pm 0.18$ & 444 & $0.51 \pm 0.17$ & 453 & $0.51 \pm 0.17$ & 453 \\
\hline Protorhus longifolia & PRU120030 & 8.3 & 249 & $0.11 \pm 0.05$ & 2264 & $0.07 \pm 0.02$ & 1186 & $0.11 \pm 0.05$ & 1915 & $0.11 \pm 0.05$ & 2264 \\
\hline Searsia Chirindensis & PMDN 333 & 3.1 & 93 & $0.16 \pm 0$ & 581 & $0.11 \pm 0.05$ & 845 & $0.31 \pm 0.01$ & 300 & $0.26 \pm 0.09$ & 358 \\
\hline Searsia leptodictya & NEL94/1969 & 6.1 & 183 & $0.13 \pm 0.05$ & 1408 & $0.42 \pm 0.18$ & 436 & $0.22 \pm 0.0 .8$ & 832 & $0.26 \pm 0.09$ & 704 \\
\hline Searsia magaliesmontana & NEL68/1997 & 18.8 & 564 & $0.17 \pm 0.02$ & 3318 & $0.17 \pm 0.02$ & 3318 & $0.52 \pm 0.18$ & 1085 & $0.52 \pm 0.18$ & 1085 \\
\hline Searsia pyroides & PMDN 570 & 3.8 & 114 & $0.13 \pm 0.05$ & 877 & $0.13 \pm 0.05$ & 877 & $0.21 \pm 0.09$ & 543 & $0.21 \pm 0.09$ & 543 \\
\hline Searsia undulata & PRU120031 & 12.5 & 375 & $0.07 \pm 0.02$ & 3409 & $0.05 \pm 0.02$ & 3409 & $0.11 \pm 0.05$ & 3409 & $0.11 \pm 0.05$ & 2885 \\
\hline Sclerocarya birrea & NEL103/1967 & 6 & 180 & $0.11 \pm 0.05$ & 1636 & $0.11 \pm 0.05$ & 1636 & $0.22 \pm 0.08$ & 818 & $0.22 \pm 0.08$ & 818 \\
\hline Smodingium argutum & PMDN 188 & 3.7 & 111 & $0.26 \pm 0.09$ & 427 & $0.26 \pm 0.09$ & 427 & $0.13 \pm 0.05$ & 854 & $0.13 \pm 0.05$ & 854 \\
\hline Searsia lancea L & PMDN 750 & 10.6 & 318 & $0.26 \pm 0.08$ & 1223 & $0.26 \pm 0.08$ & 1223 & $0.26 \pm 0.08$ & 1223 & $0.26 \pm 0.08$ & 1223 \\
\hline $\mathrm{CIP}(\mu \mathrm{g} / \mathrm{ml})$ & & & & $0.013 \pm 0.006$ & & $0.10 \pm 0.05$ & & $0.013 \pm 0.006$ & & $>10$ & \\
\hline $\mathrm{INH}(\mu \mathrm{g} / \mathrm{ml}$ & & & & $10.42 \pm 3.61$ & & $2.08 \pm 0.90$ & & $10.42 \pm 3.61$ & & $>100$ & \\
\hline $\mathrm{RIF} \mu \mathrm{g} / \mathrm{ml}$ & & & & $1.04 \pm 0.45$ & & $0.26 \pm 0.11$ & & $1.04 \pm 0.45$ & & $>100$ & \\
\hline Strep $\mu \mathrm{g} / \mathrm{ml}$ & & & & $>100$ & & $0.33 \pm 0.11$ & & $>100$ & & $>100$ & \\
\hline Acetone mg/ml & & & & $>2.5$ & & $>2.5$ & & $>2.5$ & & $>2.5$ & \\
\hline
\end{tabular}


Table 3 Pearson's correlation coefficient ( $r$ ) between MIC values of tested Mycobacteria

\begin{tabular}{|c|c|c|c|c|c|c|}
\hline & Ma & Mf & Ms & H37Ra & $M b$ & MDR-TB \\
\hline Ma & 1 & & & & & \\
\hline Mf & 0.618446398 & 1 & & & & \\
\hline MS & 0.617321739 & 0.199127491 & 1 & & & \\
\hline H37Ra & 0.870642628 & 0.920401301 & 0.370758612 & 1 & & \\
\hline$M b$ & -0.00599 & 0.61934 & 0.25880 & 0.340997 & 1 & \\
\hline MDR-TB & -0.05668 & 0.65105 & 0.10159 & 0.34707 & 0.98450 & 1 \\
\hline
\end{tabular}

Ma, Mycobacterium aurum; Mf, Mycobacterium fortuitum; Ms, Mycobacterium smegmatis; H37Ra, Mycobacterium tuberculosis

ATCC strain 25177; Mb, Mycobacterium bovis; MDR-TB, Multidrug resistant Mycobacterium tuberculosis.

The bolded values represent the correlation between rapidly growing Mycobacteria and pathogenic Mycobacteria. 
Table 4 Cytotoxicity ( $\mathrm{LC}_{50}$ in $\mathrm{mg} / \mathrm{mL}$ ) of extracts and selectivity index against C3A liver cells, Vero kidney cells and RAW 264.7 murine macrophage cells

$\begin{array}{lll}\text { SI C3 A } & \text { SI Vero cells } & \text { SI RAW cells }\end{array}$

\begin{tabular}{|c|c|c|c|c|c|c|c|c|c|c|c|c|c|c|c|}
\hline Plant species & $\mathrm{LC}_{50}$ & MA & MF & MS & MDR-TB & $\mathrm{LC}_{50}$ & MA & MF & MS & MDR-TB & $\mathrm{LC}_{50}$ & MA & MF & MS & MDR-TB \\
\hline Heeria argentea & 0.314 & 0.627 & 1.045 & 1.206 & 1.493 & 0.499 & 0.998 & 1.663 & 1.919 & 2.375 & NT & NT & NT & NT & NT \\
\hline Lannea discolor & 0.408 & 2.148 & 2.148 & 3.139 & 0.785 & NT & NT & NT & NT & NT & $>1 \mathrm{mg} / \mathrm{ml}$ & & & & \\
\hline Protorhus longifolia & 0.621 & 5.642 & 5.642 & 8.866 & 5.642 & 0.883 & 8.024 & 8.024 & 12.609 & 8.024 & $>1 \mathrm{mg} / \mathrm{ml}$ & & & & \\
\hline Searsia undulata & 0.034 & 0.488 & 0.488 & 0.380 & 0.311 & 0.496 & 7.083 & 7.083 & 5.509 & 4.507 & 0.123 & 1.751 & 1.751 & 1.362 & 1.115 \\
\hline Sclerocarya birrea & 0.169 & 0.326 & 1.304 & 0.807 & 0.770 & 0.499 & 0.959 & 3.836 & 2.375 & 2.267 & NT & & & & \\
\hline
\end{tabular}


Figure 1

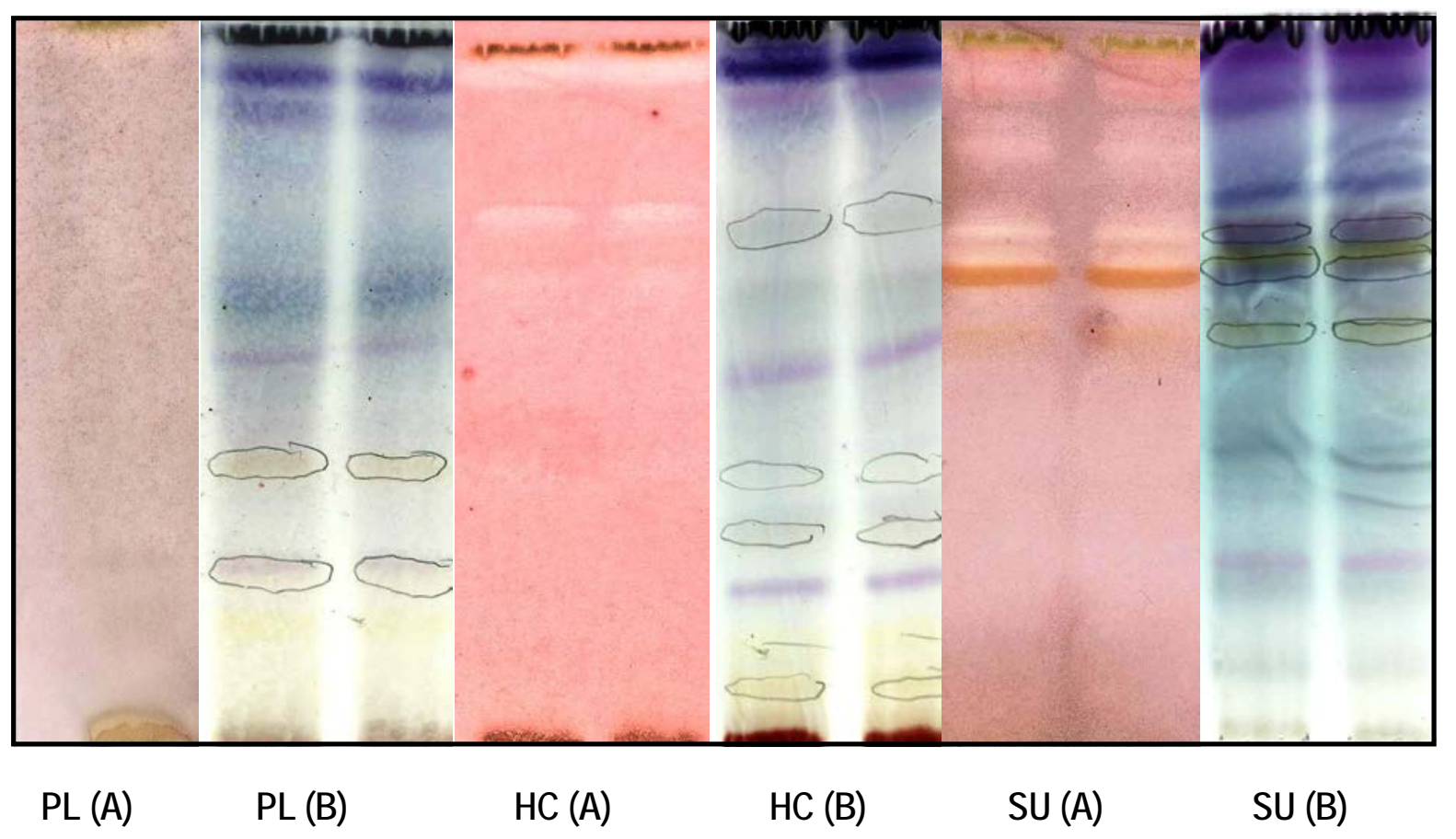

PL: Protorhus longifolia, HC: Harpephyllum caffrum, SU: Searsia undulata

Figure 4.3 Bioautogram (A) of the three plants extracts with low MIC values and thin layer chromatography plates eluted in chloroform/ethyl acetate/formic (CEF) solvent system sprayed with vanillin sulphuric acid (B) showing varied chemical constituents. Bioautogram of the screened plants against Mycobacterium aurum 